\title{
Synthesis and Annealing Temperature Effect on Structural, Optical and Electrical Properties of NiO Thin Films Deposited by Sol-Gel Technique
}

\author{
Said Benramache ${ }^{1}$, Yacine Aoun ${ }^{2}$, Rime Gacema ${ }^{1}$, and Hou- \\ da Mourghadea ${ }^{1}$ \\ ${ }^{1}$ Material Sciences Department, Faculty of Science, \\ University of Biskra, \\ 07000 Biskra, Algeria \\ ${ }^{2}$ Mechanical Department, Faculty of Technology, \\ University of El-Oued, \\ 3900 El-Oued, Algeria
}

In the present paper, thin $\mathrm{NiO}$ films are prepared on glass substrates, using spin-coating method for sol-gel solution with a concentration of 0.7 M. There were the $\mathrm{NiO}$ films annealed at different temperatures of 25 , $450,500,550$ and $600^{\circ} \mathrm{C}$ for 2 hours. XRD spectra indicate that the films exhibit polycrystalline structure, which belongs to the cubic type of $\mathrm{NiO}$. It is obtained that the crystallite sizes are increased to the maximum value of $50.32 \mathrm{~nm}$ along (200) plane and obtained at $600^{\circ} \mathrm{C}$. The crystallinity of the thin films is improved at a high temperature, for which there are only a few defects. UV-vis spectrophotometric detection of $\mathrm{NiO}$ films shows an average transmittance of about $85 \%$. The band-gap energy is increased after annealing from 3.101 to $3.855 \mathrm{eV}$ for unannealed films and annealed ones at $500^{\circ} \mathrm{C}$, respectively. At high annealing temperature, the thin $\mathrm{NiO}$ films become less disordered with fewer defects, which are related to the Urbach energy that can be obtained by the order of magnitude as $180 \mathrm{meV}$ at $600^{\circ} \mathrm{C}$. The transparent thin $\mathrm{NiO}$ films become conducting to have a minimum value of the sheet resistance that is revealed at a lower temperature. The best-estimated structure and optical characterization are achieved for the $\mathrm{NiO}$ films annealed at $500^{\circ} \mathrm{C}$.

У даній статті тонкі плівки $\mathrm{NiO}$ готували на скляних підкладинках методою центрифугування золь-гель-розчину із концентрацією у $0,7 \mathrm{M}$. Тут плівки $\mathrm{NiO}$ було відпалено за різних температур у 25, 450, 500, 550 і $600^{\circ} \mathrm{C}$ протягом 2 годин. Спектри XRD вказують на те, що плівки демонструють полікристалічну структуру, що належить до кубічного типу NiO. Розміри кристалітів є збільшеними до максимального зна- 
чення у 50,32 нм вздовж площини (200) і одержані за температури у $600^{\circ} \mathrm{C}$. Кристалічність тонких плівок поліпшувалася за високої температури, за якої присутні занадто мало дефектів. Спектрофотометрична аналіза у видимому й ультрафіолетовому діяпазонах плівок $\mathrm{NiO}$ демонструє середній коефіцієнт пропускання близько 85\%. Ширина забороненої (енергетичної) зони зросла після відпалу від 3,101 до 3,855 еВ для невідпалених і відпалених плівок при $500^{\circ} \mathrm{C}$ відповідно. За високої температури відпалу тонкі плівки $\mathrm{NiO}$ стають менш розупорядкованими із меншою кількістю дефектів, пов'язаних з енергією Урбаха, яку можна одержати за порядком величини як 180 меВ при $600^{\circ} \mathrm{C}$. Прозорі тонкі плівки $\mathrm{NiO}$ стають провідними, і мінімальне значення опору листа було виявлено при більш низькій температурі. Найліпші розрахункова структура й оптична характеризація досягаються для відпаленої плівки $\mathrm{NiO}$ при $500^{\circ} \mathrm{C}$.

Key words: $\mathrm{NiO}$, thin films, transparent conducting films, annealing temperature, spin-coating method.

Ключові слова: $\mathrm{NiO}$, тонкі плівки, прозорі провідні плівки, температура відпалу, метода центрифугування для одержання покриттів.

(Received 23 April, 2020)

\section{INTRODUCTION}

Based on latest researches on the investigation of new materials, various nanostructured materials composed of binary semiconductor compounds, such as $\mathrm{In}_{2} \mathrm{O}_{3}, \mathrm{ZnO}, \mathrm{Cu}_{2} \mathrm{O}, \mathrm{SnO}_{2}$ and $\mathrm{CdO}$, have been investigated for several applications [1, 2]. Naturally, oxides of nickel may exist in various forms, such as $\mathrm{NiO}, \mathrm{NiO}_{2}, \mathrm{NiO}_{4}$, and $\mathrm{Ni}_{2} \mathrm{O}_{3}$ [13]. However, the transparent conductive oxide (TCO) films have been attracted significant attention in optoelectronic devices [4]. Among these materials, $\mathrm{NiO}$ is appropriate for UV photodetectors and $p$-type electrical conductivity [5]. NiO has been intensively studied as a promising material for gas sensors because of its wide band gap (3.6-4.0 eV) and high stability that is similar to $\mathrm{ZnO}$ [6].

Nickel oxide ( $\mathrm{NiO})$, which is one of the most important binary semiconductor compounds, has potential applications in memory devices, $p$-type oxide semi-conductors, sensors, UV detectors, solar cells, transparent diodes, UV photodetectors, touch screens, transparent transistors, displays, and defrosting windows [1-6]. Nanocrystalline thin $\mathrm{NiO}$ films can be produced by several techniques such as reactive evaporation [7], molecular beam epitaxy (MBE) [8], magnetron sputtering technique [9], pulsed laser deposition (PLD) [10], spray pyrolysis [11], sol-gel process [12], chemical vapour deposition, and electrochemical deposition [13]. 
The influence of annealing temperature on structural and optical properties of thin $\mathrm{NiO}$ films (especially, undoped thin $\mathrm{NiO}$ films) derived from sol-gel method was less studied. The choice of temperature in range between 450 and $600^{\circ} \mathrm{C}$ is important study with deposition of the thin films on glass substrate. We observe that the glass substrate was brittle at a temperature higher than $600^{\circ} \mathrm{C}$.

This paper presents new results of the effect of the annealing temperature on the crystalline structure, optical and electrical properties of $\mathrm{NiO}$ films, and thin $\mathrm{NiO}$ films on glass substrate by spin-coating method using homogeneous and stable nickel nitrate hexahydrate with a concentration of $0.7 \mathrm{M}$.

\section{EXPERIMENTAL DETAILS}

\subsection{Preparation of Precursor Sol}

$\mathrm{NiO}$ solution was prepared by dissolving $(0.7 \mathrm{M})$ nickel nitrate hexahydrate in the solvent containing equal volumes of absolute $\mathrm{H}_{2} \mathrm{O}$; then, there have added drops of $\mathrm{HCl}$ stabilized; the mixture solution was stirred and heated at $25-50^{\circ} \mathrm{C}$ for $3 \mathrm{~h}$ to yield a clear and transparency solution. The coating was made one day after the precursor was prepared.

The substrate was R217102 glass with a size of $1 \mathrm{~cm} \times 2 \mathrm{~cm} \times 0.1$ $\mathrm{cm}$; prior to pumping, the substrate (R217102 glass) was cleaned with alcohol in an ultrasonic bath and blow-dried with dry nitrogen gas.

\subsection{Deposition of Thin Films}

The first sample was prepared by dropping the coating solution onto glass substrate, which was rotated between 2000 and $2500 \mathrm{rpm}$ for $25 \mathrm{~s}$ by using spin coater. The coating process was repeated for eight times to obtain a thin film. The preheat-treatment temperature of $150^{\circ} \mathrm{C}$ is required for the complete evaporation of organics and the initiation of formation and crystallization of the $\mathrm{NiO}$ film. After the deposition of five layers, the resulting thin films were annealed at $0^{\circ} \mathrm{C}, 450^{\circ} \mathrm{C}, 500^{\circ} \mathrm{C}, 550^{\circ} \mathrm{C}$ and $600^{\circ} \mathrm{C}$ in air for $2 \mathrm{~h}$.

\subsection{Characterization of Thin Films}

The crystal phase and crystalline orientation of the thin films were determined by x-ray diffraction (XRD, Bruker D8 advanced x-ray diffractometer) with $\mathrm{Cu} K_{\alpha}$ radiation $(\lambda=1.541 \AA)$ analysis; the samples were scanned from $30^{\circ}$ to $55^{\circ}$. The optical transmission 
spectra of the films were measured in the range of 300-1200 nm using a double-beam Lambda $35 \mathrm{UV} /$ visible spectrophotometer. In addition, the electrical conductivity of the films was measured in a coplanar structure obtained with evaporation of four golden stripes on film surface. All spectra were measured at room temperature.

\section{RESULTS AND DISCUSSION}

\subsection{The Crystalline Structure of Thin NiO Films}

The XRD patterns for thin $\mathrm{NiO}$ films deposited on glass substrates at different annealing temperatures of $450,500,550$ and $600^{\circ} \mathrm{C}$ for $2 \mathrm{~h}$ in air are shown in Fig. 1; XRD spectra indicate that the films exhibit polycrystalline structure that belongs to the cubic type of $\mathrm{NiO}$. As can be seen, the films show XRD peaks at $37.2^{\circ}$ and $43.3^{\circ}$, which correspond to the (111) and (200) crystal planes, respectively, of the cubic NiO phase ((JCPDS) No. 73-1519) [14]. For the increasing of annealing temperature from 450 to $550^{\circ} \mathrm{C}$, it can be obtained that the (111) peak has higher intensity with the preferred orientation with (111) plane; however, the film annealed at $600^{\circ} \mathrm{C}$ has

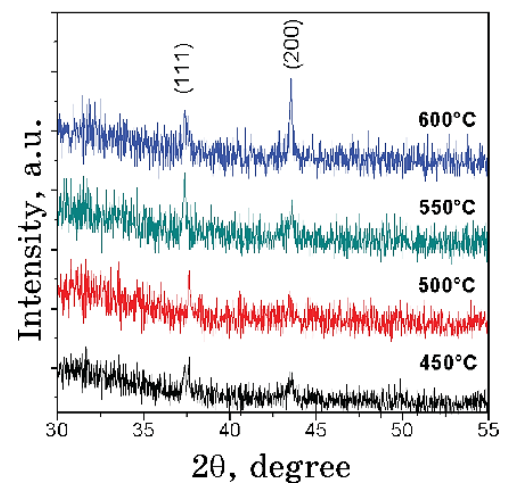

Fig. 1. X-ray diffraction spectra of thin $\mathrm{NiO}$ films annealed at different temperatures.

TABLE 1. The structural parameters of thin NiO film as a function of the annealing temperature according to (111) diffraction peak.

\begin{tabular}{c|c|c|c|c|c}
\hline Annealing temperature, ${ }^{\circ} \mathrm{C}$ & $2 \theta$, degree & $\beta$, degree & $G, \mathrm{~nm}$ & $a, \mathrm{~nm}$ & $\varepsilon_{X X}, \%$ \\
\hline 450 & 37.62 & 0.189 & 44.41 & 0.4138 & -3.896 \\
500 & 37.62 & 0.184 & 45.61 & 0.4138 & -3.896 \\
550 & 37.36 & 0.179 & 46.85 & 0.4166 & -1.120 \\
600 & 37.36 & 0.191 & 44.14 & 0.4166 & -1.120 \\
\hline
\end{tabular}


higher and sharper diffraction peaks indicating an improvement in (200) peak intensity compared to other films, revealing that the films are nanocrystalline with a preferred orientation with (200) plane perpendicular to substrate.

The diffraction peak angles of thin $\mathrm{NiO}$ films were estimated (Table 1), and the lattice parameter $a$ for these films was calculated from XRD patterns by using the following equation [15]:

$$
d_{h k l}=\frac{a}{\sqrt{\left(h^{2}+k^{2}+l^{2}\right)}},
$$

where $a$ is the lattice parameter, $h, k$ and $l$ are the Miller indices of the planes, and $d_{h k l}$ is the interplanar spacing. The variations of lattice parameter are shown in Tables 1 and 2.

In order to attain the detailed structure information, the grains' sizes $G$ of (111) and (200) planes were calculated according to the Scherrer equation [16]:

$$
G=\frac{0.9 \lambda}{\beta \cos \theta},
$$

where $G$ is the crystallite size, $\lambda$ is the x-ray wavelength $(\lambda=1.5406$ $\AA$ ); $\beta$ is the full width at half-maximum (FWHM), and $\theta$ is Bragg angle of the diffraction peaks; their variations are shown in Tables 1 and 2.

The variation of crystallite sizes of thin $\mathrm{NiO}$ films according to (111) and (200) diffraction peaks as a function of annealing temperature is shown in Fig. 2. As can be seen, the crystallite sizes were varying in the range of 37 and $52 \mathrm{~nm}$ (see Tables 1 and 2). It can be see that the crystallite sizes of (111) and (200) plans increase with increasing of annealing temperature from 450 to $550^{\circ} \mathrm{C}$. Approximation of the crystallite sizes of (111) plans is high than those of (200) plans for annealing temperature smaller than $550^{\circ} \mathrm{C}$. However, the film annealed at $600^{\circ} \mathrm{C}$ has a highest crystallite sizes of (200) plans in comparison with other. On the other hand, it can be noted that the optimal values of the average crystallite size of the

TABLE 2. The structural parameters of thin $\mathrm{NiO}$ film as a function of the annealing temperature according to (200) diffraction peak.

\begin{tabular}{ccccc|c|c}
\hline Annealing temperature, ${ }^{\circ} \mathrm{C}$ & $2 \theta$, degree & $\beta$, degree & $G, \mathrm{~nm}$ & $a, \mathrm{~nm}$ & $\varepsilon_{X X}, \%$ \\
\hline 450 & 43.58 & 0.23 & 37.19 & 0.4150 & -2.664 \\
500 & 43.40 & 0.22 & 38.86 & 0.4167 & -1.026 \\
550 & 43.58 & 0.21 & 40.74 & 0.4150 & -2.664 \\
600 & 43.52 & 0.17 & 50.32 & 0.4156 & -2.120 \\
\hline
\end{tabular}




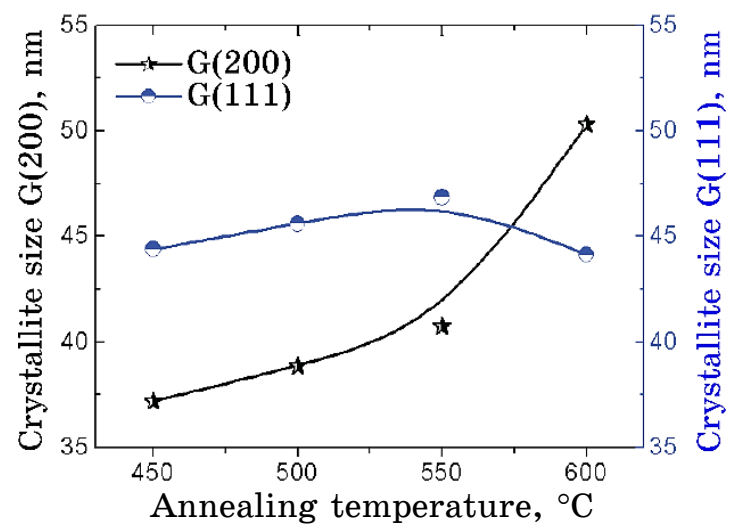

Fig. 2. The variation of crystallite size $G$ according to the (111) and (200) diffraction peaks as a function of annealing temperatures of thin $\mathrm{NiO}$ films.

$\mathrm{NiO}$ films under consideration are observed beginning from $550^{\circ} \mathrm{C}$ of annealing temperature. The increase of the crystallite size has been indicated by the enhancement of the crystallinity and $a$-axis orientation of thin $\mathrm{NiO}$ films; these phenomena were observed in Refs. [1-6]. This result can be explained by coalescence of the crystallites of the thin films improved with oxygen diffusion [16].

The dislocation density $(\delta)$ defined as the length of dislocation lines per unit volume has been estimated using the equation [17]

$$
\delta=\frac{1}{G^{2}},
$$

where $\delta$ is the measure of the amount of defects in a crystal. At a first glance, we can see that the values of $\delta$ depend on the annealing temperature (see Table 3). In Figure 3, it is presented the variation of the dislocation density $\delta$ according to (111) and (200) diffraction peaks that indicates that the effect of annealing temperature on the crystallization of thin $\mathrm{NiO}$ films can be observed at $600^{\circ} \mathrm{C}$.

The lattice parameters are substrate dependent; the mean strain $\varepsilon_{X X}$ values for thin $\mathrm{NiO}$ films can be calculated following formula [18]:

$$
\varepsilon_{X X}=\frac{a-a_{0}}{a_{0}} \cdot 100 \%,
$$

where $\varepsilon_{X X}$ is the mean strain in thin NiO films (see Tables 1 and 2), $a$ is the lattice parameter of thin $\mathrm{NiO}$ films, and $a_{0}$ is the lattice constant of bulk $\mathrm{NiO}$ material (standard $a_{0}=0.41769 \mathrm{~nm}$ ).

The variation of mean strain of (002) peak for thin NiO films is 
TABLE 3. The dislocation density $(\delta)$ of thin NiO films according to the (111) and (200) diffraction peaks as a function of annealing temperatures.

\begin{tabular}{|c|c|c|c|c|}
\hline $\begin{array}{l}\text { Annealing temperature, } \\
\text { The dislocation density }\end{array}$ & 450 & 500 & 550 & 600 \\
\hline$\delta_{(111)} \cdot 10^{-4}$ & 5.072 & 4.807 & 4.556 & 5.133 \\
\hline$\delta_{(200)} \cdot 10^{-4}$ & 7.227 & 6.620 & 6.025 & 3.950 \\
\hline
\end{tabular}

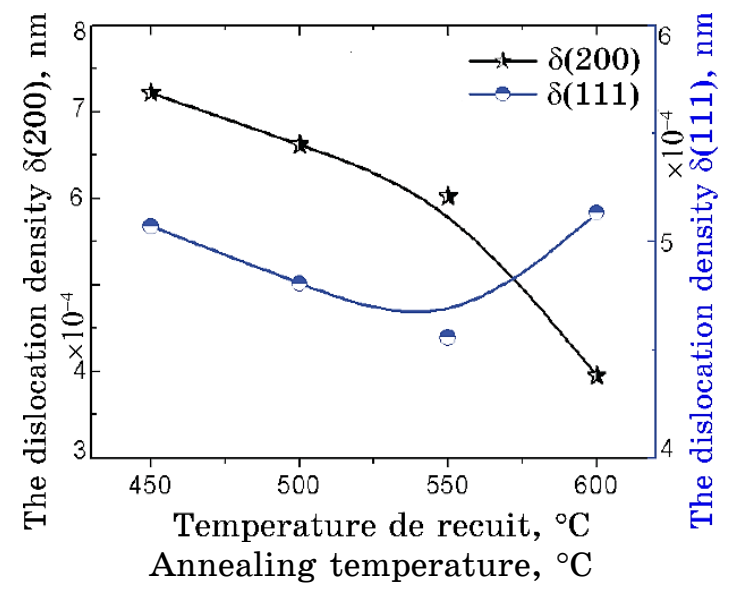

Fig. 3. The variation of dislocation density $\delta$ according to the (111) and (200) diffraction peaks as a function of annealing temperatures of thin NiO films.

presented in Tables 1 and 2 . As can be seen, all values of the mean strains are measured in a tensile condition, and the negative values of the mean strains were observed in thin $\mathrm{NiO}$ films.

\subsection{The Optical Properties of Thin NiO Films}

The optical transmission of thin NiO films measured as a function of the wavelength is presented in Fig. 4. It shows the optical transmission spectra of thin $\mathrm{NiO}$ films deposited at different annealing temperatures. As can be seen, for the longer wavelengths $(\lambda>400 \mathrm{~nm})$, all the films become transparent; it is also found that all the films show a high optical transmission, around $80 \%$, in the visible region. The optical absorption at the absorption edge corresponds to the transition from valence band to the conduction band $(\lambda>400 \mathrm{~nm})$, while the absorption in the visible region was related to some local energy levels caused by intrinsic defects. As clearly 


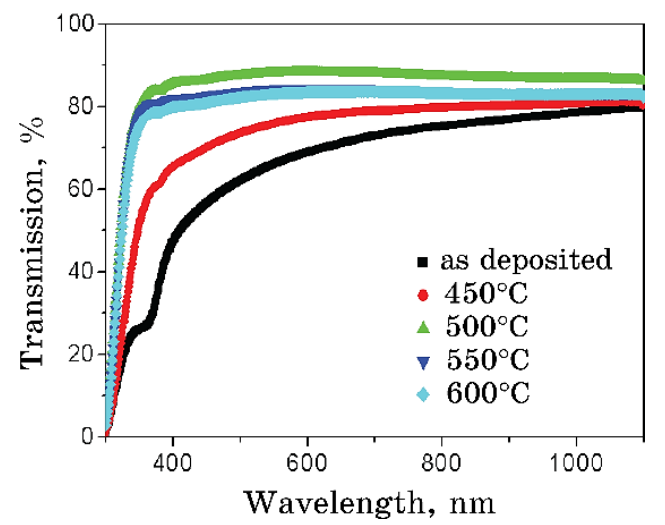

Fig. 4. Variation of spectral transmittance $(T)$ with wavelength $(\lambda)$ for thin $\mathrm{NiO}$ film annealed at different temperatures.

TABLE 4. Variation of the optical band-gap energy and the Urbach energy of thin $\mathrm{NiO}$ films with different annealing temperatures.

\begin{tabular}{cc|c}
\hline Annealing temperatures, ${ }^{\circ} \mathrm{C}$ & Optical gap energy $E_{g}, \mathrm{eV}$ & Urbach energy $E_{u}, \mathrm{meV}$ \\
\hline As deposited & 3.101 & 454.976 \\
450 & 3.536 & 339.311 \\
500 & 3.855 & 191.036 \\
550 & 3.847 & 206.179 \\
600 & 3.854 & 180.756 \\
\hline
\end{tabular}

seen in this region, the transmission is decreased because of the onset fundamental absorption in the region of 300-350 $\mathrm{nm}$.

The optical band-gap energy (Table 2) for thin NiO films is obtained by the following expressions [19]:

$$
\begin{gathered}
A=\alpha d=-\ln T, \\
(A h v)^{2}=C\left(h v-E_{g}\right),
\end{gathered}
$$

where $A$ is the absorbance, $d$ is the film thickness, $T$ is the spectral transmittance of thin films, $\alpha$ is the absorption coefficient value, $C$ is a constant, $h v$ is the photon energy, and $E_{g}$ is the band-gap energy for the semiconductor. The values of $E_{g}$ and $\Delta E_{g}$ are listed in Table 4. On the other hand, we have used the Urbach energy $\left(E_{u}\right)$, which is related to the disorder in the film network, as it is expressed as follows [19]:

$$
A=A_{0} \exp \left(h v / E_{u}\right)
$$


where $A_{0}$ is a constant, $h v$ is the photon energy, and $E_{u}$ is the Urbach energy, which is presented in Table 4.

The graph of $(A h v)^{2}$ versus $h v$ plotted for $\mathrm{NiO}$ films fabricated at different annealing temperatures is shown in Fig. 5 , $a$. It can be seen that the extrapolation of linear portion of the graph to the energy axis at $A=0[30,31]$ in the range of $300-350 \mathrm{~nm}$ gives band gap energy $E_{g}$ shown in Table 2. Besides, Figure 5, $a$ shows the graph of $\ln A$ versus $h v$ plotted to be used to deduce the Urbach energy [19].

Figure 6 shows the variations of the band-gap energy $E_{g}$ and the Urbach energy $E_{u}$ as functions of the annealing temperatures. The optical gap and disorder vary inversely. It is observed that the band-gap energy and Urbach energy of thin $\mathrm{NiO}$ films are increased after annealing; this result can be explained by nickel hydroxide
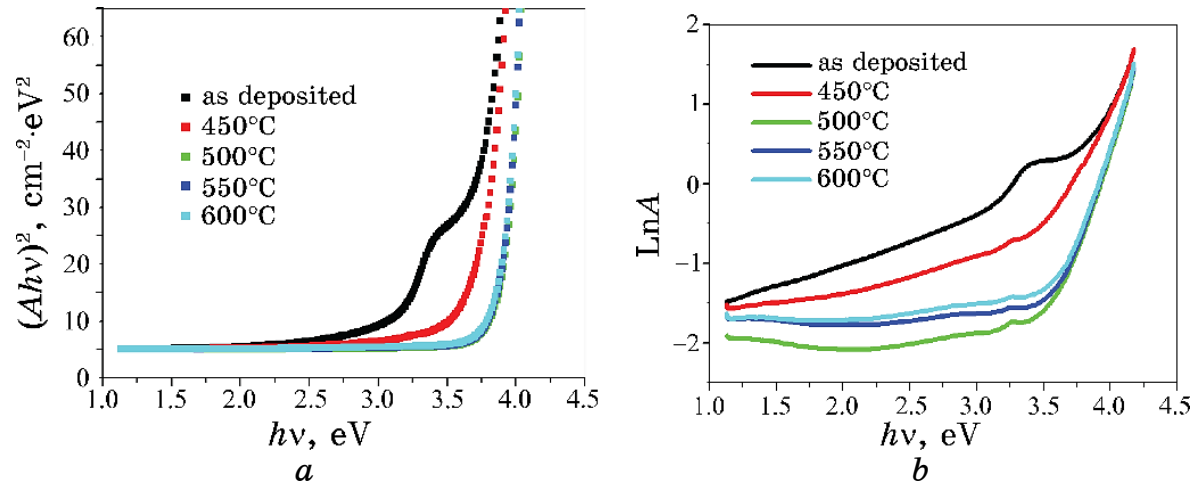

Fig. 5. Typical variations of $(A h v)^{2}$ and $\ln A$ drawn as functions of photon energy $h v$ and used, respectively, for the band-gap energy $(a)$ and Urbach energy $(b)$ determination by means of extrapolation.

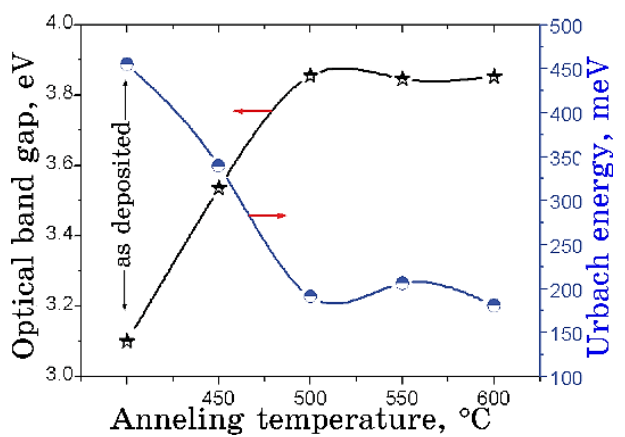

Fig. 6. The variations of optical band gap $E_{g}$ and Urbach energy $E_{u}$ for thin $\mathrm{NiO}$ films with annealing temperature. 
found as deposited and can be decreased as evaporated with annealing at temperature, which is located between 500 and $600^{\circ} \mathrm{C}$. This result can be explained by increasing the transmission of the films (see Fig. 4). The increasing optical gap at 500 and $600^{\circ} \mathrm{C}$ can indicate on oxygen diffusion with annealing. As can be seen in Fig. 6, a minimum Urbach energy for thin $\mathrm{NiO}$ film is reached between 500 and $600^{\circ} \mathrm{C}$ that means that this is a temperature adequate for less disorder; this can be explained by increasing of the crystallite size (see Fig. 2).

\subsection{The Electrical Conductivity of Thin NiO Films}

The four-point probe is preferred for measurement of sheet resistance $\left(R_{s h}\right)$; in the linear four-point probe technique, the current $(I)$ is applied between the two outer leads, and the potential difference $(V)$ is measured across the two inner probes [33]. Since negligible contact and spreading resistance associated with the voltage probes, one can obtain a fairly accurate estimation of $R_{s h}$, using the following relation $[20]$ :

$$
R_{s h}=\frac{\pi}{\ln (2)} \frac{V}{I}
$$

where $I$ is the applied current, and $V$ is the measured voltage. In the above-mentioned configuration, a correction factor of 4.532 was applied for the sample $2 \mathrm{~cm} \times 1 \mathrm{~cm}$ with equally spaced $\left(2 \mathrm{~cm}^{2}\right)$ probes. Figure 7 gives the sheet resistance $R_{s h}$. The result shows the conductivity of thin $\mathrm{NiO}$ film with increasing annealing tempera-

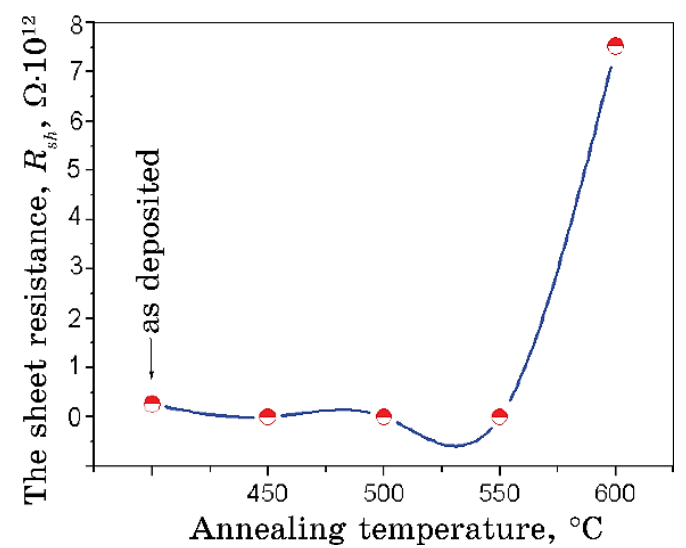

Fig. 7. The variation of electrical resistance of thin $\mathrm{NiO}$ films with annealing temperature. 
tures. This is due to the increasing of the strain (because of fewer defects) (see Tables 1 and 2).

\section{CONCLUSION}

In summary, high-quality transparent thin $\mathrm{NiO}$ films were grown on glass substrates at room temperature by sol-gel-solution spincoating method; the influence of annealing temperature on structural, optical, and electrical properties was investigated. The coated $\mathrm{NiO}$ films were annealed in air for 2 hours at different temperatures of $0,450,500,550$ and $600^{\circ} \mathrm{C}$. The films were obtained at a concentration of sol-gel solution of $0.7 \mathrm{M}$. XRD spectra indicate that the films exhibit polycrystalline structure that belongs to the cubic type of NiO. The crystallite sizes of $\mathrm{NiO}$ thin films were increasing with increasing annealing temperature, reaching the maximum value of $50.32 \mathrm{~nm}$ for $(200)$ plane obtained at $600^{\circ} \mathrm{C}$. The crystallinity of the thin films is improved at high annealing temperature that was dependent on a few defects. Spectrophotometry (UV-vis) of $\mathrm{NiO}$ films deposited at different annealing temperatures shows an average transmittance of about $85 \%$. The band-gap energy is increased after annealing from $E_{g}=3.101$ to $3.855 \mathrm{eV}$ for unannealed and annealed films at $500^{\circ} \mathrm{C}$, respectively. At high annealing temperature, the thin $\mathrm{NiO}$ films become less disordered with a fewer defects that is related to the Urbach energy, which can be obtained by the order of magnitude as $180 \mathrm{meV}$ at $600^{\circ} \mathrm{C}$. The transparent semiconductor thin $\mathrm{NiO}$ films become conducting to have a minimum value of the sheet resistance $R_{s h}$ found at lower temperature. The best-estimated structure and optical characterisation are achieved for annealed $\mathrm{NiO}$ film at $600^{\circ} \mathrm{C}$.

\section{REFERENCES}

1. N. Beji, M. Reghima, M. Souli, and N. K. Turki, J. Alloys Compd., 675: 231 (2016).

2. Y. Aoun, B. Benhaoua, B. Gasmi, and S. Benramache, Main Group Chem., 14: 27 (2015).

3. F. Cinquini, L. Giordano, and G. Pacchioni, Theor. Chem. Account., 120: 575 (2008).

4. H. S. Gavale, M. S. Wagh, R. B. Ahirrao, and S. R. Gosavi, Journal of Nanoscience and Technology, 5: 610 (2019).

5. X. Chen, L. Zhao and Q. Niu, J. Elect. Mater., 41: 3382 (2012).

6. Y. Shin, Y. Hwang, Y. Um, D. A. Tuan, S. Cho, and H. Park, J. Korean Phys. Soc., 63: 1199 (2013).

7. D. S. Dalavi, M. J. Suryavanshi, S. S. Mali, D. S. Patil, and P. S. Patil, J. Solid State Electrochemistry, 16, No. 1: 253 (2012). 
8. K. O. Ukoba, A. C. Eloka-Eboka, and F. L. Inambao, Renewable and Sustainable Energy Reviews, 82: 2900 (2018).

9. T. Miyata, H. Tanaka, H. Sato, and T. Minami, J. Mater. Sci., 41: 5531 (2006).

10. Y. S. Lin, D. J. Lin, L. Y. Chiu, and S. W. Lin, J. Solid State Electrochemistry, 16: 2581 (2012).

11. X. C. Lou, X. J. Zhao, Y. L. Xiong, and X. T. Sui, J. Sol-Gel Sci. Technol., 54: 43 (2010).

12. C. Chen, P. J. Perdomo, M. Fernandez, and A. Barbeito, Journal of Energy Storage, 8: 198 (2016).

13. Y. A. Kumar Reddy, B. Ajitha, P. S. Reddy, M. S. Pratap Reddy, and J. H. Lee, Electron. Mater. Lett., 10: 907 (2014).

14. A. Diha, S. Benramache, and B. Benhaoua, Optik, 172: 832 (2018).

15. S. Benramache, Y. Aoun, S. Lakel, H. Mourghade, R. Gacem, and B. Benhaoua, Journal of Nano- and Electronic Physics, 10: 06032 (2018).

16. S. Benramache and B. Benhaoua, Superlattices Microstruct., 52: 1062 (2012).

17. H. L. Chen, Y. M. Lu, and W. S. Hwang, Mater. Transact., 46: 872 (2005).

18. S. Benramache, B. Benhaoua, and O. Belahssen, Optik, 125: 5864 (2014).

19. Y. Aoun, B. Benhaoua, S. Benramache, and B. Gasmi, Optik, 126: 5407 (2015).

20. B. Benhaoua, S. Abbas, A. Rahal, A. Benhaoua, and M. S. Aida, Superlattices Microstruct., 83: 78 (2016). 